\title{
Influence of solution chemistry on the inactivation of particle- associated viruses by UV irradiation
}

Zhe Feng ${ }^{1}$, Ruiqing $\mathrm{Lu}^{2}$, Baoling Yuan ${ }^{1 *}$, Zhenming Zhou ${ }^{1}$, Qingqing $\mathrm{Wu}^{1}$, Thanh $\mathrm{H}$.

Nguyen ${ }^{2 *}$

${ }^{1}$ Institute of Municipal and Environmental Engineering, College of Civil Engineering, Huaqiao University, Xiamen, Fujian 361021, P. R. China

${ }^{2}$ Department of Civil and Environmental Engineering, University of Illinois at Urbana-Champaign, 205 N. Mathews Ave., Urbana, IL 61801;

${ }^{*}$ Corresponding authors. Tel: +86 592616 2780; +1 217-244-5965

E-mail address: yuanbl@ hotmail.com; thn@illinois.edu 


\section{Abstract}

MS2 inactivation by UV irradiance was investigated with the focus on how the disinfection efficacy is influenced by bacteriophage MS2 aggregation and adsorption to particles in solutions with different compositions. Kaolinite and Microcystis aeruginosa were used as model inorganic and organic particles, respectively. In the absence of model particles, MS2 aggregates formed in either $1 \mathrm{mM} \mathrm{NaCl}$ at $\mathrm{pH}=3$ or 50-200 mM ionic strength $\mathrm{CaCl}_{2}$ solutions at $\mathrm{pH}=7$ led to a decrease in the MS2 inactivation efficacy because the virions located inside the aggregate were protected from the UV irradiation. In the presence of kaolinite and Microcystis aeruginosa, MS2 adsorbed onto the particles in either $1 \mathrm{mM} \mathrm{NaCl}$ at $\mathrm{pH}=3$ or $50-200 \mathrm{mM} \mathrm{CaCl}_{2}$ solutions at $\mathrm{pH}=7$. In contrast to $\mathrm{MS} 2$ aggregates formed without the presence of particles, more MS2 virions adsorbed on these particles were exposed to UV irradiation to allow an increase in MS2 inactivation. In either $1 \mathrm{mM} \mathrm{NaCl}$ at $\mathrm{pH}$ from 4 to 8 or $2-200 \mathrm{mM} \mathrm{NaCl}$ solutions at $\mathrm{pH}=7$, the absence of MS2 aggregation and adsorption onto the model particles explained why MS2 inactivation was not influenced by $\mathrm{pH}$, ionic strength, and the presence of model particles in these conditions. The influence of virus adsorption and aggregation on the UV disinfection efficiency found in this research suggests the necessity of accounting for particles and cation composition in virus inactivation for drinking water.

Keywords: UV disinfection, MS2, kaolinite, Microcystis aeruginosa, particle-association. 


\section{Introduction}

Virus disinfection can be a serious challenge in providing safe drinking water. However, not enough attention has been paid to virus disinfection compared to bacteria disinfection because of the lack of systematic monitoring of viruses in most countries. Many human enteric viruses, like rotavirus, norovirus, and enterovirus, could cause outbreaks of infectious diseases [1]. Severe diarrhea for children under the age of 5 due to rotavirus infection caused up to 591,000 deaths/year in 2000 and 233,000 deaths/year in 2013 [2]. Hepatitis A and hepatitis E viral infections could be related to untreated or improperly treated drinking water [3]. Hepatitis E infection is particularly severe for pregnant women, with the mortality rate as high as $25 \%$ [4]. Norovirus transmits through the fecal-oral route and causes acute gastroenteritis among people of all ages [5]. To prevent the transmission of human pathogenic viruses, special attention needs to be paid to virus disinfection in water treatment.

Most physical processes in water treatment, including coagulation, sedimentation, and granular filtration, are not capable of sufficiently removing viruses because of the nanometer size of the virions [6] and the unfavorable virus aggregation or adsorption to sand surfaces [7-9]. For these reasons, the control of virus contamination in drinking water relies on disinfection processes. Chlorination, ozonation, and UV irradiation are widely accepted disinfection processes. Compared to chlorination, UV irradiation has the advantage of producing less toxic disinfection byproducts (DBP) [10]. Though ozone is a strong disinfectant [11], the high cost of operation and maintenance and the production of toxic bromate DBP are of concern [12, 13]. UV disinfection has some advantages over chlorination and ozonation, because of the lack of toxic DBP formation and the relatively low cost, respectively [14].

In this study, we investigated how virus disinfection by UV irradiation is influenced 
by virus aggregation and adsorption to suspended particles. While in physical treatment processes including coagulation and filtration, the occurrence of virus aggregation or adsorption to suspended particles has been reported to increase the virus removal [15-17], it is not understood yet how the virus aggregation or adsorption to suspended particles would influence the virus disinfection by UV irradiation. Bacteria disinfection efficacy by UV irradiation has been shown to decrease when bacteria cells adsorbed to suspended particles [18]. However, this observation may not be applicable for virus disinfection due to the different structures of virus and bacteria.

We hypothesize that virus aggregation and adsorption influence virus disinfection efficacy by UV irradiation due to the decrease in UV exposure. Algae bloom has become one of most serious water problem in south China $[19,20]$. Because algal particles are difficult to neutralize and destabilize under the conditions relevant for drinking water treatment in south China [21], the removal of algae is usually not satisfactory, allowing them to be present in the disinfection reactor [22]. Besides algae, inorganic particles could also be present, especially if the water source is turbid surface water. These inorganic particles could influence the virus disinfection efficacy by UV irradiation. For these reasons, the influence of Microcystis aeruginosa, a model algae, and kaolinite, a model inorganic particle, on virus disinfection efficacy by UV irradiation is investigated in this study. Bacteriophage MS2 is used as the surrogate for enteric viruses for their similarities in size and structure [23]. MS2 aggregation and adsorption to suspended particles are studied under relevant environmental factors including $\mathrm{pH}$ conditions, concentrations of suspended particles, and cation concentrations [7, 24]. By understanding the influence of water source chemical composition on the relationship between the disinfection efficacy and virus 
adsorption/aggregation, virus disinfection by UV irradiation can be better controlled for safe water treatment.

\section{Materials and Methods}

\subsection{Material and Solution Preparation}

Analytical grade $\mathrm{NaOH}, \mathrm{HCl}$, and $\mathrm{NaHCO}_{3}$ were purchased from Sinopharm Chemical Reagent CO., Ltd (Shanghai, China). Kaolinite was purchased from Sigma-Aldrich (United States). Mediums for MS2 propagation (solid, semisolid, and liquid) were purchased from Qingdao Hope Bio-Technogy Co., Ltd (Qingdao, China). MS2 (ATCC 15597-B1) and its E. coli host (ATCC 15597) were purchased from American Type Culture Collection (ATCC, Manassas, USA). Microcystis aeruginosa was supplied by the Institute of Hydrobiology, Chinese Academy of Sciences (Wuhan, China).

\subsection{MS2 Propagation and Purification}

The method for MS2 propagation and purification was reported previously [17, 25]. Briefly, the ATCC 15597 E. coli was used as the host bacteria for MS2. The E. coli was amplified in the tryptic soy broth liquid media at $37^{\circ} \mathrm{C}$ and shaken at $200 \mathrm{rpm}$. The MS2 was inoculated into the $E$. coli suspension when the absorbance at $420 \mathrm{~nm}$ wavelength reached 0.8 . The MS2 incubation lasted for 24 hours at $37{ }^{\circ} \mathrm{C}$ with the suspension shaken at $200 \mathrm{rpm}$. After incubation, the bacteria debris were precipitated by centrifuge at $5000 \mathrm{rpm}$ for 15 minutes, and were further removed by filtering the supernatant with a $0.2 \mu \mathrm{m}$ Millipore hydrophilic membrane (Bedford, MA). Further purification of the MS2 stock was conducted in a Millipore stirred cell with a Koch 10 kDa MWCO membrane (Wilmington, MA). Each $200 \mathrm{~mL}$ MS2 suspension was washed constantly with $1 \mathrm{~L}$ of the $1 \mathrm{mM} \mathrm{NaHCO}_{3}$ solution. The residue of the growth media was washed away, while the MS2 bacteriophage was retained in the stirred cell 
by the membrane. The retained MS2 suspension was used as the stock solution for the MS2 inactivation experiment. The MS2 concentration was determined with the plaque forming unit (PFU) method as previously described [26].

\subsection{Hydrodynamic Diameter and Electrophoretic Mobility (EPM) Measurement for}

\section{Particles}

The hydrodynamic diameters and the EPMs of MS2, kaolinite, and Microcystis aerugunosa were determined with a Malvern NanoZS90 Zetasizer (Southeborough, MA) at $25{ }^{\circ} \mathrm{C}$. The concentration of MS2, kaolinite, and Microcystis aerugunosa in the measurement were $1.0 \times 10^{11} \mathrm{pfu} / \mathrm{mL}, 100 \mathrm{mg} / \mathrm{L}$, and $1.0 \times 10^{5}$ Cells $/ \mathrm{mL}$, respectively. There were 3 replicates in each measurement. The hydrodynamic diameters of MS2, kaolinite, and Microcystis aerugunosa were measured at $\mathrm{pH}=7$ in 1 $\mathrm{mM} \mathrm{NaCl}$ solution. The EPMs were measured at $\mathrm{pH}$ from 3.0 to 8.0. The solution $\mathrm{pH}$ was adjusted by $1 \mathrm{~mol} / \mathrm{L} \mathrm{NaOH}$ and $\mathrm{HCl}$. The EPMs were also determined in ionic strength from $2 \mathrm{mM}$ to $200 \mathrm{mM}$ for $\mathrm{NaCl}$ and $\mathrm{CaCl}_{2}$ solutions at $\mathrm{pH}=7.0$.

\subsection{MS2 Adsorption onto Kaolinite and Microcystis aeruginosa}

$100 \mathrm{mg} / \mathrm{L}$ kaolinite (or $10^{5}$ Cells/mL Microcystis aeruginosa) was prepared in $\mathrm{NaCl}$ or $\left(\mathrm{CaCl}_{2}\right.$ solution $)$ at a certain ionic strength. The solution $\mathrm{pH}$ was adjusted to the target value with $1 \mathrm{~mol} / \mathrm{L} \mathrm{NaOH}$ or $\mathrm{HCl}$ solution. $0.1 \mathrm{~mL} \mathrm{MS} 2$ at a concentration of $1.0 \times 10^{8} \mathrm{pfu} / \mathrm{mL}$ was added to $100 \mathrm{~mL}$ of the particle suspension. The mixture was shaken at $200 \mathrm{rpm}$ at $25{ }^{\circ} \mathrm{C}$ for 24 hours. The sample was then centrifuged at $2000 \mathrm{~g}$ for 30 minutes to separate the suspended and the particle-associated MS2. The MS2 in the supernatant was quantified with the PFU method [27]. A control experiment in the absence of suspended particles was performed in DI water. Three replicates were conducted for each experiment.

\subsection{MS2 Inactivation by UV Irradiation}


The UV collimated beam apparatus (CBA) with only significant UV emission at $253.7 \mathrm{~nm}$ was constructed as recommended by the USEPA [28]. $20 \mathrm{~mL}$ of sample in a quartz dish was gently stirred and exposed to the UV irradiation. Prior to each experiment, the CBA was stabilized for 30 minutes to obtain a stable UV irradiation. Every inactivation experiment was replicated twice. A UV dosage of $40 \mathrm{~mJ} / \mathrm{cm}^{2}$ was chosen because this is the recommended UV dosage in water treatment [29]. The actual UV dosage was determined with the method described previously [30]. Briefly, the average germicidal fluence rate $\mathrm{E}_{\text {avg }}^{\prime}$ (UV intensity) in the water was calculated as the product of the radiometer reading at the center of the dish at a vertical position $\left(E_{0}\right)$, the ratio of the average of the incident irradiance over the area of the petri dish to the irradiance at the center of the dish $\left(P_{f}=0.96\right)$, the reflection factor $\left(R_{f}=\right.$ 0.975), the water absorption factor $\left(W_{f}\right)$, and the divergent factor $\left(D_{f}\right) . W_{f}$ is a water factor, which accounts for the decrease in irradiance arising from absorption as the beam passed through the water, and it is defined as:

$$
W_{f}=\frac{1-10^{-a l}}{\mathrm{a} l \ln (10)}
$$

where $a$ is the absorbance for a $1 \mathrm{~cm}$ path length $\left(\mathrm{cm}^{-1}\right)$, and $l$ is the vertical path length $(\mathrm{cm})$ of the water in the petri dish. $D_{f}$ is the divergence factor because the beam is not perfectly collimated and diverges significantly:

$$
D_{f}=\frac{L}{l+\mathrm{L}}
$$

$\mathrm{L}$ is the distance from the UV lamp to the surface of the cell suspension. $\left(E_{\text {avg }}^{\prime} \times t\right)$ is a constant.

A control experiment to determine MS2 desorption from particles was conducted in the absence of UV irradiation. After adsorption, a sample was taken from the suspension solution and then was injected into elution solution to elute the adsorbed MS2 by continuous shaking with vortexing oscillator. The elution solution consisted 
of $8.5 \mathrm{~g} \mathrm{NaCl}$ and $1.0 \mathrm{~g}$ tryptone dissolved in $1000 \mathrm{~mL}$ sterile ultrapure water, and the solution $\mathrm{pH}$ was adjusted to 7 [31]. The protein-rich eluent disrupts electrostatic bonds between the virus and particle and detaches adsorbed viruses from particle surfaces. MS2 inactivation was calculated based on the infectivity of MS2 present in the solution after elution, including both the unabsorbed MS2 and the MS2 desorbed from particles. The MS2 inactivation in the presence and the absence of particles was compared. Duplicate experiments were conducted for each condition.

\subsection{The Extended DLVO (XDLVO) Interaction Energy Profiles}

MS2 aggregation and adsorption onto suspended particles were interpreted with the XDLVO theory regarding the energy of van der Waals force $\left(\Phi_{v d W}\right)$, electrostatic force $\left(\Phi_{d l}\right)$ and the Lewis acid-base force $\left(\Phi_{A B}\right)$, as functions of the separation distance $h(n m)$.

$$
\Phi_{X D L V O}(h)=\Phi_{v d W}(h)+\Phi_{d l}(h)+\Phi_{A B}(h)
$$

Since the hydrodynamic diameters of kaolinite, Microcystis aeruginosa, and MS2 are measured to be 1-10 $\mu \mathrm{m}, 3 \mu \mathrm{m}$, and $26 \mathrm{~nm}$, respectively, kaolinte and Microcystis aeruginosa were considered as plane surfaces in the MS2 adsorption. The MS2-particles $\Phi_{v d W}$ was calculated with the following expression [32]:

$$
\Phi_{v d W}(\mathrm{~h})=-\frac{A_{123} r_{p}}{6 h}\left[1+\left(\frac{14 h}{\lambda}\right)\right]^{-1}
$$

where $A_{M S 2-H_{2} O-\text { kaolinite }}$ is $7.50 \times 10^{-21} \mathrm{~J}$ and $A_{M S 2-H_{2} O-F a c h b}$ is $2.0 \times 10^{-21}$ J. $r_{p}(13 \mathrm{~nm})$ is the MS2 radius. $\lambda\left(10^{-7} \mathrm{~m}\right)$ is the characteristic wavelength of the sphere-plate interactions. The $\Phi_{d l}(h)$ was calculated as [33]:

$$
\Phi_{d l}(h)=\pi \varepsilon_{r} \varepsilon_{0} r_{p}\left[2 \Psi_{p} \Psi_{s} \ln \left(\frac{1+e^{-\kappa h}}{1-e^{-\kappa h}}\right)+\left(\Psi_{p}^{2}+\Psi_{s}^{2}\right) \ln \left(1-e^{-2 \kappa h}\right)\right]
$$

The $\Phi_{A B}(h)$ was calculated as [34]: 


$$
\Phi_{A B}(h)=2 \pi r_{p} \lambda_{A B} \Phi_{A B\left(h=h_{0}\right)} \exp \left[\frac{h_{0}-h}{\lambda_{A B}}\right]
$$

where $\lambda_{A B}(1 \mathrm{~nm})$ is the water's decay length [35]. $\Phi_{A B\left(h=h_{0}\right)}\left(\mathrm{J} / \mathrm{m}^{2}\right)$ is the Lewis acid-base free energy of interaction between particles as $\mathrm{h}=\mathrm{h}_{0}$. For MS2-kaolinite, MS2-Microcystis aeruginosa, and MS2-MS2, $\Phi_{A B\left(h=h_{0}\right)}$ is $-5.35 \times 10^{-6} \mathrm{~J} / \mathrm{m}^{2}$, $-3.2 \times 10^{-7} \mathrm{~J} / \mathrm{m}^{2}$, and $-2.69 \times 10^{-6}$, respectively, with $\mathrm{h}_{0}=0.25 \mathrm{~nm}$.

The interaction energy between MS2 virions was calculated using a sphere-sphere model [36, 37]:

$$
\Phi_{v d W}(\mathrm{~h})=-\frac{A_{123}}{12}\left\{\frac{1}{\xi^{2}+\xi+\xi}+\frac{1}{\xi^{2}+\xi+\xi+1}+2 \ln \left[\frac{\xi^{2}+\xi+\xi}{\xi^{2}+\xi+\xi+1}\right]\right\}
$$

where

$$
\xi=\frac{h}{r_{p}}
$$

$\Phi_{d l}(h), \Phi_{A B}(h)$ were calculated as follows [33, 38]:

$$
\begin{gathered}
\left.\Phi_{d l}(h)=\pi \varepsilon_{r} \varepsilon_{0} \frac{r_{p}}{2}\left[2 \Psi_{p}^{2} \ln \left(\frac{1+e^{-\kappa h}}{1-e^{-\kappa h}}\right)+2 \Psi_{p}^{2}\right) \ln \left(1-e^{-2 \kappa h}\right)\right] \\
\Phi_{A B}(h)=\pi \lambda_{A B} r_{p} \Phi_{A B\left(h=h_{0}\right)} \exp \left[\frac{h_{0}-h}{\lambda_{A B}}\right]
\end{gathered}
$$

\section{Results and Discussion}

\subsection{Effect of Particle Concentration on MS2 Inactivation by UV irradiation}

As shown in Fig. 1 , in $1 \mathrm{mM} \mathrm{NaCl}$ solution at $\mathrm{pH}=7.0$, the $\log _{10}$ inactivation of MS2 remained at about $2.5 \log _{10}$ with the concentration of kaolinite and Microcystis aeruginosa varying from 0 to $100 \mathrm{mg} / \mathrm{L}$ and 0 to $10^{6} \mathrm{Cells} / \mathrm{mL}$, respectively. The concentration of particles had no significant impact on the inactivation of MS2. Templeton et al. [39] found that the kaolin clay particles did not result in a statistical reduction in $\log _{10}$ inactivation of MS2 at two UV dose (40 and $80 \mathrm{~J} / \mathrm{m}^{2}$ and $\left.\mathrm{pH}=5.5\right)$. 
Our observation is consistent with a previous report that kaolinite and Microcystis aeruginosa did not protect MS2 from the UV irradiation at $\mathrm{pH}=7.0$. The UV absorbance by suspended particles became greater with the increasing concentration of particles. To make sure that the UV dose delivered to MS2 was not affected by the elevated particle concentrations [39], the irradiation time was increased propotionally to achieve the same dose (i.e. from 376 s for particle-free water to 430 s for the 100mg/L kaolinite solution in Fig. 1(A)).

\section{FIGURE 1}

\subsection{Effect of pH on MS2 Inactivation by UV in the Presence of Particles}

As shown in Fig. 2, the MS2 inactivation in particle-free solution increased from 1.7 to $2.5 \log _{10}$ with the $\mathrm{pH}$ changing from 3.0 to 8.0 . The higher MS2 inactivation at $\mathrm{pH}=8.0$ can be attributed to the lack of MS2 aggregation. As shown in Fig. 3, at $\mathrm{pH}=3.0$, the MS2 aggregation resulted in a $0.34 \pm 0.08 \log _{10}$ decrease of the suspended MS2 concentration, while the decrease at $\mathrm{pH}=8.0$ was only $0.03 \log _{10}$. MS2 aggregated at $\mathrm{pH}=3.0$ because this $\mathrm{pH}$ is close to the MS2 isoelectric point (IEP) of 3.7 [40]. Similar aggregation of MS2 has been observed with the $\mathrm{pH}$ close to IEP previously [41]. Due to the MS2 aggregation at $\mathrm{pH}=3.0$, the MS2 virions at the outer surface of the aggregate protected the virions inside the aggregates from the UV irradiation. At $\mathrm{pH}=8.0$, the repulsive electrostatic forces between MS2 particles kept the MS2 particles mono-dispersed in the suspension [6]. With each individual MS2 
particle exposed to the UV irradiation at $\mathrm{pH}=8.0$, a higher MS2 inactivation was observed compared to the aggregates at $\mathrm{pH}=3.0$. In the $\mathrm{pH}$ range from 5.0 to 8.0, MS2 inactivation did not change with $\mathrm{pH}$, as shown in Fig. 2, since MS2 particles did not aggregate in this $\mathrm{pH}$ range, as shown in Fig. 3. In summary, MS2 aggregation attenuated the UV irradiation for the virions within the aggregates and thus decreased the overall inactivation.

\section{FIGURE 2}

The influence of particles on MS2 inactivation was not consistent in the $\mathrm{pH}$ from 3.0 to 8.0. At $\mathrm{pH}=3.0$, the presence of either kaolinite or Microcystis aeruginosa increased the MS2 inactivation by $0.3 \operatorname{logs}$ compared to the particle-free solution, as shown in Fig. 2. The increase of MS2 inactivation in the presence of particles at $\mathrm{pH}=3.0$ can be attributed to the MS2 adsorption to particles. As shown in Fig. 3, the MS2 adsorption onto the kaolinite decreased the suspended MS2 concentration by $0.7 \log _{10}$, and 0.5 $\log _{10}$ for the Microcystis aeruginosa. Unlike the MS2 aggregates, where inner MS2 in the aggregate were protected by the outer MS2, MS2 adsorbed to the surface of the particles did not get protection against the UV irradiation [39]. Therefore, at $\mathrm{pH}=3.0$, MS2 adsorption onto particles increased MS2 inactivation compared to that in the absence of particles. With the $\mathrm{pH}$ higher than 4.0, the adsorption of MS2 onto particles was minimal, as shown in Fig. 3, probably because of the repulsive interaction force between MS2 and the particles, and thus the presence of particles did 
not affect the mono-dispersity of MS2 virions [25]. As a result, the MS2 inactivation in the presence and the absence of particles was not significantly different at $\mathrm{pH}$ higher than 4.0.

FIGURE 3

The observed MS2 adsorption at different $\mathrm{pH}$ values could be elucidated by the XDLVO profile, as shown in Fig. 4. $\Phi_{X D L V O} / K_{B} T$ was larger with the increasing $\mathrm{pH}$ at the same distance. The lowest energy barrier near zero was found at $\mathrm{pH}=3.0$, favoring MS2 aggregation or adsorption and consistent with the observed trend shown in Fig. 3. It is also shown in Fig. 4 that the energy barrier for MS2 adsorption onto kaolinite was greater than the adsorption onto Microcystis aeruginosa at the same $\mathrm{pH}$ (i.e., 19.1 $K_{B} T$ and $24.4 K_{B} T$, respectively, at $\mathrm{pH}=8.0$ ). This difference in energy barrier indicated that MS2 adsorbed onto kaolinite more favorably than onto Microcystis aeruginosa. Consistently, $0.1 \log _{10}$ adsorption was observed for kaolinite versus $0.03 \log _{10}$ for Microcystis aeruginosa at $\mathrm{pH}=8.0$, as shown in Fig. 3.

\section{FIGURE 4}

3.3 Effect of Ionic Strength on the MS2 Inactivation by UV in the Presence of

\section{Particles}

As shown in Fig. 5 (A), the UV inactivation of MS2 did not change with the $\mathrm{NaCl}$ 
concentration at $\mathrm{pH}=7.0$, and the MS2 inactivation efficacy remained at about 2.5 $\log _{10}$. The independence of MS2 inactivation of the $\mathrm{NaCl}$ concentration can be explained by the absence of MS2 aggregation in $\mathrm{NaCl}$ solutions. The stability of MS2 suspension due to steric repulsion of MS2 capsids has been reported previously [7, 24]. Penrod et al. attributed these steric interactions to polypeptides of loops at the capsid surface [42].

\section{FIGURE 5}

In contrast to the observation in the $\mathrm{NaCl}$ solutions, $\mathrm{Ca}^{2+}$ has a significant effect on the destabilization of MS2 virions. Fig. 5 (B) shows that the $\log _{10}$ inactivation of MS2 decreased from $2.8 \log _{10}$ to $1.2 \log _{10}$ in the particle-free solution when the ionic strength of the $\mathrm{CaCl}_{2}$ solution increased from 2 to $200 \mathrm{mM}$. The decrease of MS2 inactivation in the $\mathrm{Ca}^{2+}$ solutions can be attributed to MS2 aggregation. As shown in Fig. 6 (B), virus aggregation in $200 \mathrm{mM}$ ionic strength $\mathrm{CaCl}_{2}$ resulted in a $0.8 \log _{10}$ decrease of the suspended MS2 concentration. The enhancement of MS2 aggregation by $\mathrm{Ca}^{2+}$ due to the inner sphere complexation with carboxylate function groups on virus capsid has been reported previously [7, 43]. Because of MS2 aggregation in the presence of $\mathrm{Ca}^{2+}$, virions on the outer surface of the aggregate would protect the inner viruses from UV irradiation. This protection resulted in the observed decrease of MS2 inactivation by UV.

FIGURE 6 
In the presence of the particles (both kaolinite and Microcystis aeruginosa), MS2 inactivation was $2.5 \log _{10}$ even when the concentration of $\mathrm{Na}^{+}$increased to $200 \mathrm{mM}$ (Fig. 5 (A)). The observed independence of MS2 inactivation with the $\mathrm{NaCl}$ concentration in the solution containing particles was consistent with the lack of MS2 adsorption to these particles, as shown in Fig. 6 (A). The $\log _{10}$ adsorption of MS2 on particles remained insignificant with the increasing $\mathrm{Na}^{+}$concentration in both the kaolinite and Microcystis aeruginosa suspensions.

For the $\mathrm{CaCl}_{2}$ solutions in the presence of the model particles, the MS2 inactivation decreased by $0.76 \log _{10}$ when the ionic strength of the $\mathrm{CaCl}_{2}$ solution increased from 2 to $200 \mathrm{mM}$ (Fig. 5 (B)). The decrease of MS2 inactivation with the increasing $\mathrm{CaCl}_{2}$ concentration indicates that some MS2 virions were protected from UV irradiation in the presence of particles. It is highly possible that the adsorbed MS2 formed multiple layers on the particles surface, and thus the virions in the inner layer were not exposed to UV irradiation.

\section{FIGURE 7}

To understand MS2 adsorption onto particles, the electrophoretic mobility (EPM) of kaolinite and Microcystis aeruginosa in different ionic strengths of $\mathrm{NaCl}$ and $\mathrm{CaCl}_{2}$ solutions are shown in Fig. 7. The EPMs of kaolinite and Microcystis aeruginosa were significantly less negative in $\mathrm{CaCl}_{2}$ solutions than in $\mathrm{NaCl}$ solutions. For the kaolinite particles, the EPM in the $10 \mathrm{mM}$ ionic strength $\mathrm{CaCl}_{2}$ solution was even less 
negative than in the $200 \mathrm{mM} \mathrm{NaCl}$ solutions. The less negative $\mathrm{EPM}$ in $\mathrm{CaCl}_{2}$ solutions favors MS2 adsorption onto the kaolinite particles, compared to $\mathrm{NaCl}$ solution, as shown in Fig. 6 (A) and (B). For the Microcystis aeruginosa, the less negative $\mathrm{EPM}$ in $\mathrm{CaCl}_{2}$ solutions was also observed but not as pronounced as that for the kaolinite. However, due to the presence of carboxylate groups on the Microcystis aeruginosa surface, the previously reported complexation effect of $\mathrm{Ca}^{2+}[7,43]$ enhanced the MS2 adsorption onto Microcystis aeruginosa. Therefore, significant MS2 adsorption onto Microcystis aeruginosa was also observed, as shown in Fig. 6 (B).

In $\mathrm{CaCl}_{2}$ solutions with the ionic strength higher than $50 \mathrm{mM}$, the MS2 inactivation in the particle-free solution was significantly lower than that in the particle-containing solutions, as shown in Fig. 5 (B). Note that the suspended MS2 concentrations in the $\mathrm{CaCl}_{2}$ solutions were not significantly influenced by the presence of model particles, as shown in Fig. 6 (B), the higher MS2 inactivation in particle-containing solutions indicates that virions adsorbed onto particles were not protected from UV irradiation as well as that in the MS2 aggregate. The different effects of MS2 aggregation and adsorption can be attributed to the size of suspended particles. In the hydrodynamic diameter measurement, the size of kaolinite and Microcystis aeruginosa particles were 1-10 $\mu \mathrm{m}$ and $3 \mu \mathrm{m}$, respectively, which are orders of magnitude larger than the MS2 diameter of $26 \mathrm{~nm}$. Due to the size of kaolinite and Microcystis aeruginosa particles, there were more virions exposed to UV in the case of MS2 adsorption to particles than the MS2 aggregates that occurred in the absence of model particles. As a result, 
the presence of model particles enhanced MS2 inactivation by UV in high ionic strength $\mathrm{CaCl}_{2}$ solutions.

\section{Conclusions}

In the $\mathrm{pH}$ range from 4.0 to 8.0 in $1 \mathrm{mM} \mathrm{NaCl}$ solution, or when the concentration of $\mathrm{Na}^{+}$changed from 2 to $200 \mathrm{mM}$ in $\mathrm{pH}=7.0$ solution, the lack of MS2 aggregation or adsorption indicated that the MS2 disinfection efficiency by UV is independent of the presence of kaolinite or Microcystis aeruginosa. At $\mathrm{pH}=3.0$, the MS2 aggregation in particle-free solution reduced the UV disinfection efficacy. When particles were added to the solutions at $\mathrm{pH}=3.0, \mathrm{MS} 2$ inactivation decreased by about $0.3 \log _{10}$ because MS2 virions were more favorable of adsorbing onto the particles surface than forming MS2 aggregates. At $\mathrm{pH}=7$, the divalent ion $\mathrm{Ca}^{2+}$ enhanced the $\mathrm{MS} 2$ aggregation in the absence of model particles, leading to a reduction in the inactivation efficacy, compared to the $\mathrm{NaCl}$ solution at the same ionic strength. In the presence of particles, $\mathrm{Ca}^{2+}$ neutralized the particle surface charge or acted as a complexation bridge, promoting MS2 adsorption onto particles more than MS2 aggregation, resulting in an increase in inactivation compared to the condition without model particles.

\section{Acknowledgements}

The authors greatly appreciated the financial support from the Program for the Natural Science Foundation of China (Grant No. 51678255, 51508209), the Province 
Natural Science Fund of Fujian (Grant No. 2015J01213) and the National Science and Technology Pillar Program (Grant No. 2012BAC04B02).

\section{References}

[1] T.-T. Fong, E.K. Lipp, Enteric viruses of humans and animals in aquatic environments: health risks, detection, and potential water quality assessment tools, Microbiology and Molecular Biology Reviews, 69 (2005) 357-371.

[2] J.E. Tate, A.H. Burton, C. Boschi-Pinto, U.D. Parashar, M. Agocs, F. Serhan, L. de Oliveira, J.M. Mwenda, R. Mihigo, P.R. Wijesinghe, Global, Regional, and National Estimates of Rotavirus Mortality in Children $<5$ Years of Age, 2000-2013, Clinical Infectious Diseases, 62 (2016) S96-S105.

[3] J.M. Brunkard, E. Ailes, V.A. Roberts, V. Hill, E.D. Hilborn, G.F. Craun, A. Rajasingham, A. Kahler, L. Garrison, L. Hicks, Surveillance for waterborne disease outbreaks associated with drinking water-United States, 2007-2008, MMWR Surveill Summ, 60 (2011) 38-68.

[4] R. Aggarwal, K. Krawczynski, Hepatitis E: an overview and recent advances in clinical and laboratory research, Journal of gastroenterology and hepatology, 15 (2000) 9-20.

[5] M.Y. Lim, J.-M. Kim, G. Ko, Disinfection kinetics of murine norovirus using chlorine and chlorine dioxide, Water research, 44 (2010) 3243-3251.

[6] M.J. Mattle, B. Crouzy, M. Brennecke, K. R. Wigginton, P. Perona, T. Kohn, Impact of virus aggregation on inactivation by peracetic acid and implications for other disinfectants, Environmental science \& technology, 45 (2011) 7710-7717.

[7] L. Gutierrez, S.E. Mylon, B. Nash, T.H. Nguyen, Deposition and aggregation kinetics of rotavirus in divalent cation solutions, Environmental science \& technology, 44 (2010) 4552-4557.

[8] L. Gutierrez, T.H. Nguyen, Interactions between Rotavirus and Natural Organic Matter Isolates with Different Physicochemical Characteristics, Langmuir, 29 (2013) 14460-14468.

[9] B. Yuan, M. Pham, T.H. Nguyen, Deposition kinetics of bacteriophage MS2 on a silica surface coated with natural organic matter in a radial stagnation point flow cell, Environmental science \& technology, 42 (2008) 7628-7633.

[10] S.W. Krasner, H.S. Weinberg, S.D. Richardson, S.J. Pastor, R. Chinn, M.J. Sclimenti, G.D. Onstad, A.D. Thruston, Occurrence of a new generation of disinfection byproducts, Environmental Science \& Technology, 40 (2006) 7175-7185.

[11] G.-A. Shin, M.D. Sobsey, Reduction of Norwalk virus, poliovirus 1, and bacteriophage MS2 by ozone disinfection of water, Applied and Environmental Microbiology, 69 (2003) 3975-3978.

[12] U. von Gunten, Ozonation of drinking water: Part II. Disinfection and by-product formation in presence of bromide, iodide or chlorine, Water Research, 37 (2003) 1469-1487. 
[13] M.J. Plewa, E.D. Wagner, P. Jazwierska, S.D. Richardson, P.H. Chen, A.B. McKague, Halonitromethane drinking water disinfection byproducts: chemical characterization and mammalian cell cytotoxicity and genotoxicity, Environmental science \& technology, 38 (2004) 62-68.

[14] M.J. Lehtola, I.T. Miettinen, T. Vartiainen, P. Rantakokko, A. Hirvonen, P.J. Martikainen, Impact of UV disinfection on microbially available phosphorus, organic carbon, and microbial growth in drinking water, Water research, 37 (2003) 1064-1070. [15] T. Matsushita, N. Shirasaki, Y. Matsui, K. Ohno, Virus inactivation during coagulation with aluminum coagulants, Chemosphere, 85 (2011) 571-576.

[16] M.W. Jenkins, S.K. Tiwari, J. Darby, Bacterial, viral and turbidity removal by intermittent slow sand filtration for household use in developing countries: Experimental investigation and modeling, Water research, 45 (2011) 6227-6239.

[17] R. Lu, D. Mosiman, T.H. Nguyen, Mechanisms of MS2 Bacteriophage Removal by Fouled Ultrafiltration Membrane Subjected to Different Cleaning Methods, Environmental Science \& Technology, 47 (2013) 13422-13429.

[18] E. Walters, M. Graml, C. Behle, E. Muller, H. Horn, Influence of Particle Association and Suspended Solids on UV Inactivation of Fecal Indicator Bacteria in an Urban River, Water Air and Soil Pollution, 225 (2014).

[19] L. Xu, J. Shen, D. Marinova, X. Guo, F. Sun, F. Zhu, Changes of public environmental awareness in response to the Taihu blue-green algae bloom incident in China, Environment, development and sustainability, 15 (2013) 1281-1302.

[20] B. Qin, G. Zhu, G. Gao, Y. Zhang, W. Li, H.W. Paerl, W.W. Carmichael, A drinking water crisis in Lake Taihu, China: linkage to climatic variability and lake management, Environmental management, 45 (2010) 105-112.

[21] W.L.F.J.M. Jun, C. Zhonglin, Effect of pre-oxidation on algal cell morphology and algal removal by enhanced coagulation process, Journal of Southeast University (Natural Science Edition), (2005) S1.

[22] P. Xie, J. Ma, J. Fang, Y. Guan, S. Yue, X. Li, L. Chen, Comparison of permanganate preoxidation and preozonation on algae containing water: cell integrity, characteristics, and chlorinated disinfection byproduct formation, Environmental science \& technology, 47 (2013) 14051-14061.

[23] A. Furiga, G. Pierre, M. Glories, P. Aimar, C. Roques, C. Causserand, M. Berge, Effects of ionic strength on bacteriophage MS2 behavior and their implications for the assessment of virus retention by ultrafiltration membranes, Applied and environmental microbiology, 77 (2011) 229-236.

[24] S.E. Mylon, C.I. Rinciog, N. Schmidt, L. Gutierrez, G.C. Wong, T.H. Nguyen, Influence of salts and natural organic matter on the stability of bacteriophage MS2, Langmuir, 26 (2009) 1035-1042.

[25] B.L. Yuan, M. Pham, T.H. Nguyen, Deposition Kinetics of Bacteriophage MS2 on a Silica Surface Coated with Natural Organic Matter in a Radial Stagnation Point Flow Cell, Environmental Science \& Technology, 42 (2008) 7628-7633.

[26] O.C. Romero, A.P. Straub, T. Kohn, T.H. Nguyen, Role of temperature and Suwannee River natural organic matter on inactivation kinetics of rotavirus and bacteriophage MS2 by solar irradiation, Environmental science \& technology, 45 
(2011) 10385-10393.

[27] M.A. Bacteriophages, Interscience Publishers, Inc., New York, (1959) 446.

[28] USEPA, Ultraviolet disinfection guidance manual for the final long term 2 enhanced surface water treatment rule, US Environmental Protection Agency Washington, DC, 2006.

[29] J.R. Bolton, C.A.C. Cotton, The ultraviolet disinfection handbook, American Water Works Association2011.

[30] J.R. Bolton, K.G. Linden, Standardization of methods for fluence (UV dose) determination in bench-scale UV experiments, Journal of Environmental Engineering, 129 (2003) 209-215.

[31] D. ISO, Water quality-Detection and Enumeration of Bacteriophages-Part 1: Enumeration of F-specific RNA Bacteriophages, International Organization for Standardization Geneva, 1995.

[32] J. Gregory, Approximate expressions for retarded van der Waals interaction, Journal of Colloid and Interface Science, 83 (1981) 138-145.

[33] R. Hogg, T. Healy, D. Fuerstenau, Mutual coagulation of colloidal dispersions, Transactions of the Faraday Society, 62 (1966) 1638-1651.

[34] C. Van Oss, Interfacial forces in aqueous media, 1994, New York: Marcel Decker Inc, (2005).

[35] C. Van Oss, Acid - base interfacial interactions in aqueous media, Colloids and Surfaces A: Physicochemical and Engineering Aspects, 78 (1993) 1-49.

[36] D.L. Feke, N.D. Prabhu, J.A. Mann Jr, J.A. Mann III, A formulation of the short-range repulsion between spherical colloidal particles, The Journal of Physical Chemistry, 88 (1984) 5735-5739.

[37] J.N. Ryan, P.M. Gschwend, Effects of ionic strength and flow rate on colloid release: Relating kinetics to intersurface potential energy, Journal of Colloid and Interface Science, 164 (1994) 21-34.

[38] C. Van Oss, R. Giese, Role of the properties and structure of liquid water in colloidal and interfacial systems, Journal of dispersion science and technology, 25 (2005) 631-655.

[39] M.R. Templeton, R.C. Andrews, R. Hofmann, Inactivation of particle-associated viral surrogates by ultraviolet light, Water research, 39 (2005) 3487-3500.

[40] T.H. Nguyen, N. Easter, L. Gutierrez, L. Huyett, E. Defnet, S.E. Mylon, J.K. Ferri, N.A. Viet, The RNA core weakly influences the interactions of the bacteriophage MS2 at key environmental interfaces, Soft Matter, 7 (2011) 10449-10456.

[41] J. Langlet, F. Gaboriaud, C. Gantzer, Effects of $\mathrm{pH}$ on plaque forming unit counts and aggregation of MS2 bacteriophage, Journal of applied microbiology, 103 (2007) 1632-1638.

[42] S.L. Penrod, T.M. Olson, S.B. Grant, Deposition kinetics of two viruses in packed beds of quartz granular media, Langmuir, 12 (1996) 5576-5587.

[43] P.R. Dormitzer, Z.Y.J. Sun, G. Wagner, S.C. Harrison, The rhesus rotavirus VP4 sialic acid binding domain has a galectin fold with a novel carbohydrate binding site, The EMBO Journal, 21 (2002) 885-897. 


\section{Caption of Figures}

Fig. 1. The log inactivation of MS2 by UV as a function of the particle concentration in $1 \mathrm{mM} \mathrm{NaCl}$ solution. (A) kaolinite. (B) Microcystis aerugunosa. The concentration of bacteriophage MS2 is $1.0 \times 10^{8} \mathrm{pfu} / \mathrm{mL}$, UV dose is $40 \mathrm{~mJ} / \mathrm{cm}^{2}, \mathrm{pH}=7.0, \mathrm{~T}=25^{\circ} \mathrm{C}$.

Fig. 2. The log inactivation of MS2 by UV at different $\mathrm{pH}$ value. The concentrations of kaolinite, Microcysti aeruginosa, and MS2 are $100 \mathrm{mg} / \mathrm{L}, 1.0 \times 10^{5} \mathrm{Cells} / \mathrm{mL}$, and $1.0 \times 10^{8} \mathrm{pfu} / \mathrm{mL}$, respectively, $\mathrm{UV}$ dose is $40 \mathrm{~mJ} / \mathrm{cm}^{2}, \mathrm{~T}=25^{\circ} \mathrm{C}$.

Fig. 3. The $\log$ adsorption of MS2 at different $\mathrm{pH}$ value. The concentrations of kaolinite, Microcysti aeruginosa, and MS2 are $100 \mathrm{mg} / \mathrm{L}, 1.0 \times 10^{5}$ Cells $/ \mathrm{mL}$, and $1.0 \times 10^{8} \mathrm{pfu} / \mathrm{mL}$, respectively, $\mathrm{T}=25^{\circ} \mathrm{C}$.

Fig. 4. Calculated XDLVO profiles at different $\mathrm{pH}$ values. (A) MS2-kaolinite. (B) MS2-Microcysti aeruginosa. The concentrations of kaolinite, Microcysti aeruginosa, and MS2 are $100 \mathrm{mg} / \mathrm{L}, 1.0 \times 10^{5} \mathrm{Cells} / \mathrm{mL}$, and $1.0 \times 10^{8} \mathrm{pfu} / \mathrm{mL}$, respectively, $\mathrm{T}=25^{\circ} \mathrm{C}$.

Fig. 5. The log inactivation of MS2 by UV disinfection at different ionic strengths. (A) $\mathrm{NaCl}$. (B) $\mathrm{CaCl}_{2}$. The concentrations of kaolinite, Microcysti aeruginosa, and MS2 are $100 \mathrm{mg} / \mathrm{L}, 1.0 \times 10^{5} \mathrm{Cells} / \mathrm{mL}$, and $1.0 \times 10^{8} \mathrm{pfu} / \mathrm{mL}$, respectively, contact time is 1 minute, $\mathrm{pH}=7.0, \mathrm{~T}=25^{\circ} \mathrm{C}$.

Fig. 6. The log adsorption of MS2 at different ionic strengths. (A) $\mathrm{NaCl}$. (B) $\mathrm{CaCl}_{2}$. The concentrations of kaolinite, Microcysti aeruginosa, and MS2 are $100 \mathrm{mg} / \mathrm{L}$, $1.0 \times 10^{5} \mathrm{Cells} / \mathrm{mL}$, and $1.0 \times 10^{8} \mathrm{pfu} / \mathrm{mL}$, respectively, $\mathrm{pH}=7.0, \mathrm{~T}=25^{\circ} \mathrm{C}$.

Fig. 7. The electrophoretic mobility of (A) kaolinite and (B) Microcystis aeruginosa at different ionic strengths of $\mathrm{NaCl}$ (black squares) and $\mathrm{CaCl}_{2}$ (red circles). The concentrations of kaolinite and Microcysti aeruginosa are $100 \mathrm{mg} / \mathrm{L}$ and $1.0 \times 10^{5}$ Cells/mL, respectively, $\mathrm{pH}=7.0, \mathrm{~T}=25^{\circ} \mathrm{C}$. 

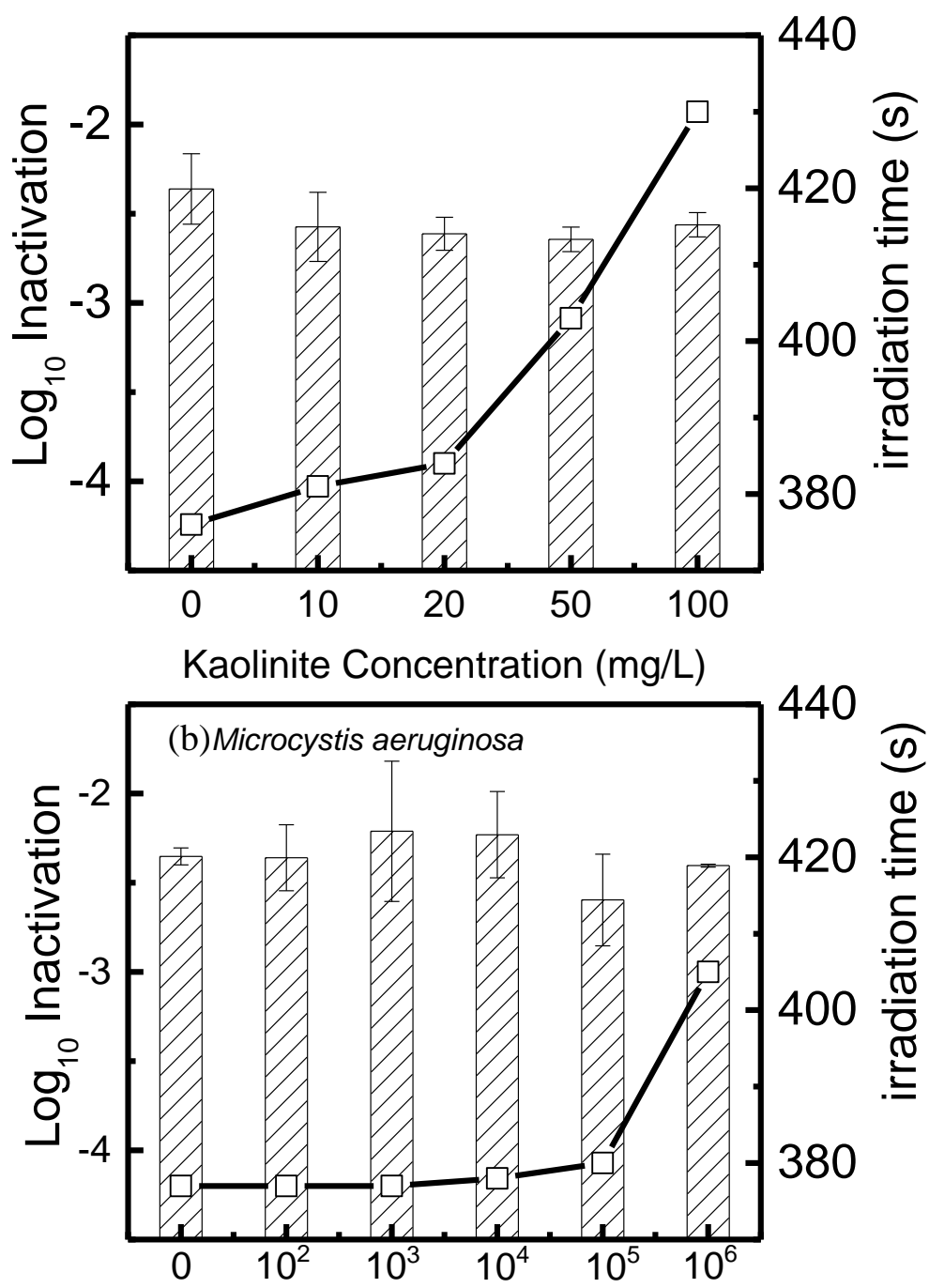

Microcystis aeruginosa Concentration (Cell/mL) $\nabla / 7 \log _{10}$ inactivation - $\square$ - irradiation time

Fig. 1. The log inactivation of MS2 by UV as a function of the particle concentration in $1 \mathrm{mM} \mathrm{NaCl}$ solution. (A) kaolinite. (B) Microcystis aerugunosa. The concentration of bacteriophage MS2 is $1.0 \times 10^{8} \mathrm{pfu} / \mathrm{mL}, \mathrm{UV}$ dose is $40 \mathrm{~mJ} / \mathrm{cm}^{2}, \mathrm{pH}=7.0, \mathrm{~T}=25^{\circ} \mathrm{C}$. 


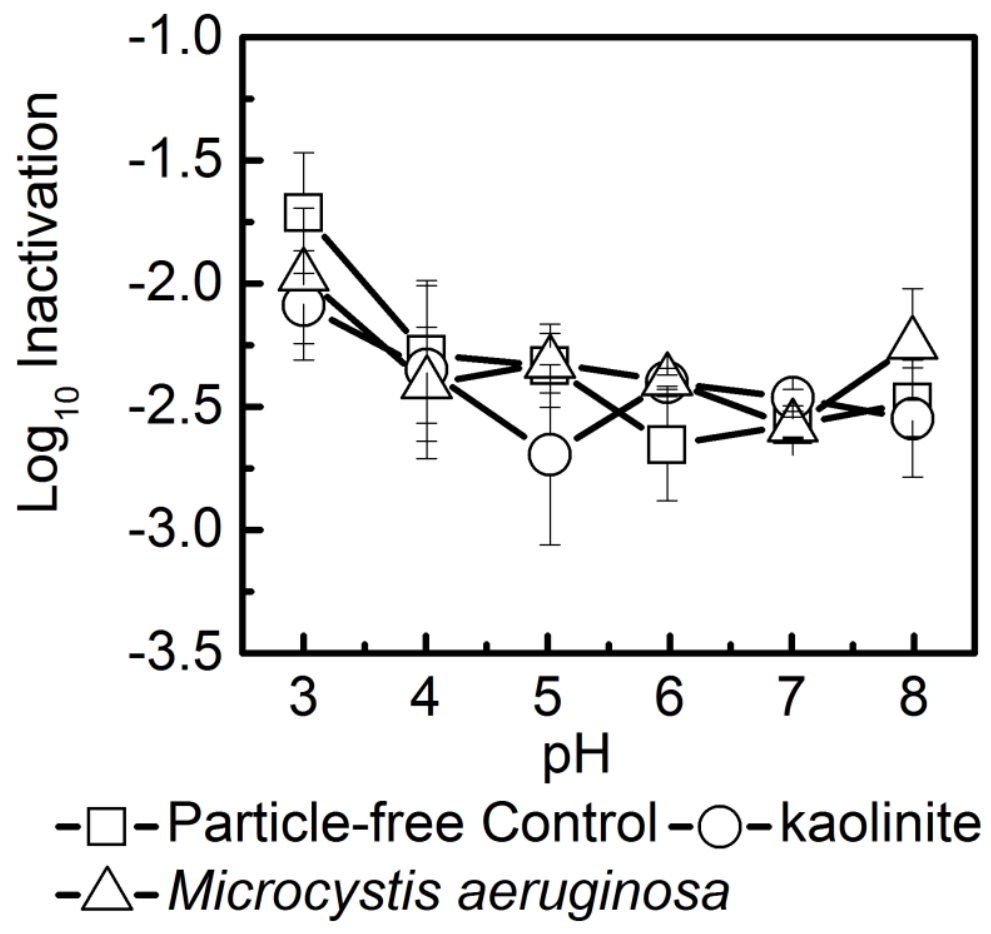

Fig. 2. The log inactivation of MS2 by UV at different $\mathrm{pH}$ value. The concentrations of kaolinite, Microcysti aeruginosa, and MS2 are $100 \mathrm{mg} / \mathrm{L}, 1.0 \times 10^{5} \mathrm{Cells} / \mathrm{mL}$, and $1.0 \times 10^{8} \mathrm{pfu} / \mathrm{mL}$, respectively, UV dose is $40 \mathrm{~mJ} / \mathrm{cm}^{2}, \mathrm{~T}=25^{\circ} \mathrm{C}$. 


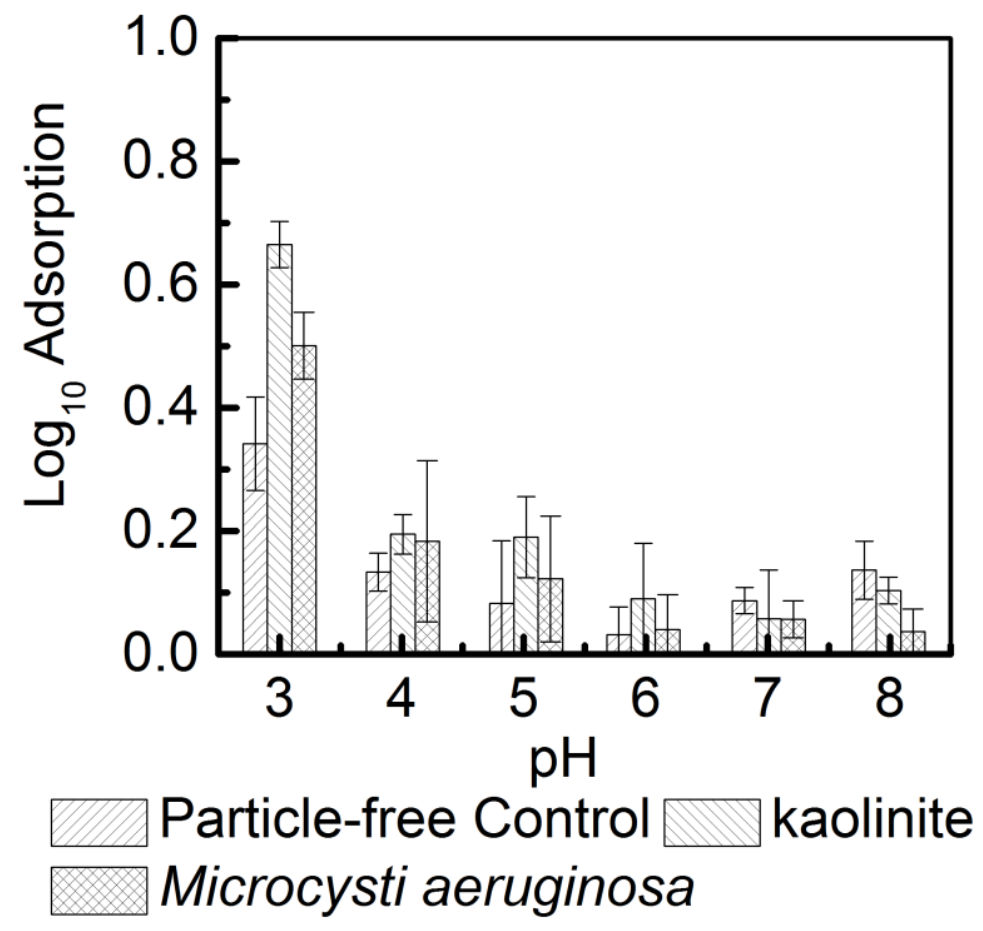

Fig. 3. The $\log$ adsorption of MS2 at different $\mathrm{pH}$ value. The concentrations of kaolinite, Microcysti aeruginosa, and MS2 are $100 \mathrm{mg} / \mathrm{L}, 1.0 \times 10^{5}$ Cells $/ \mathrm{mL}$, and $1.0 \times 10^{8} \mathrm{pfu} / \mathrm{mL}$, respectively, $\mathrm{T}=25^{\circ} \mathrm{C}$. 

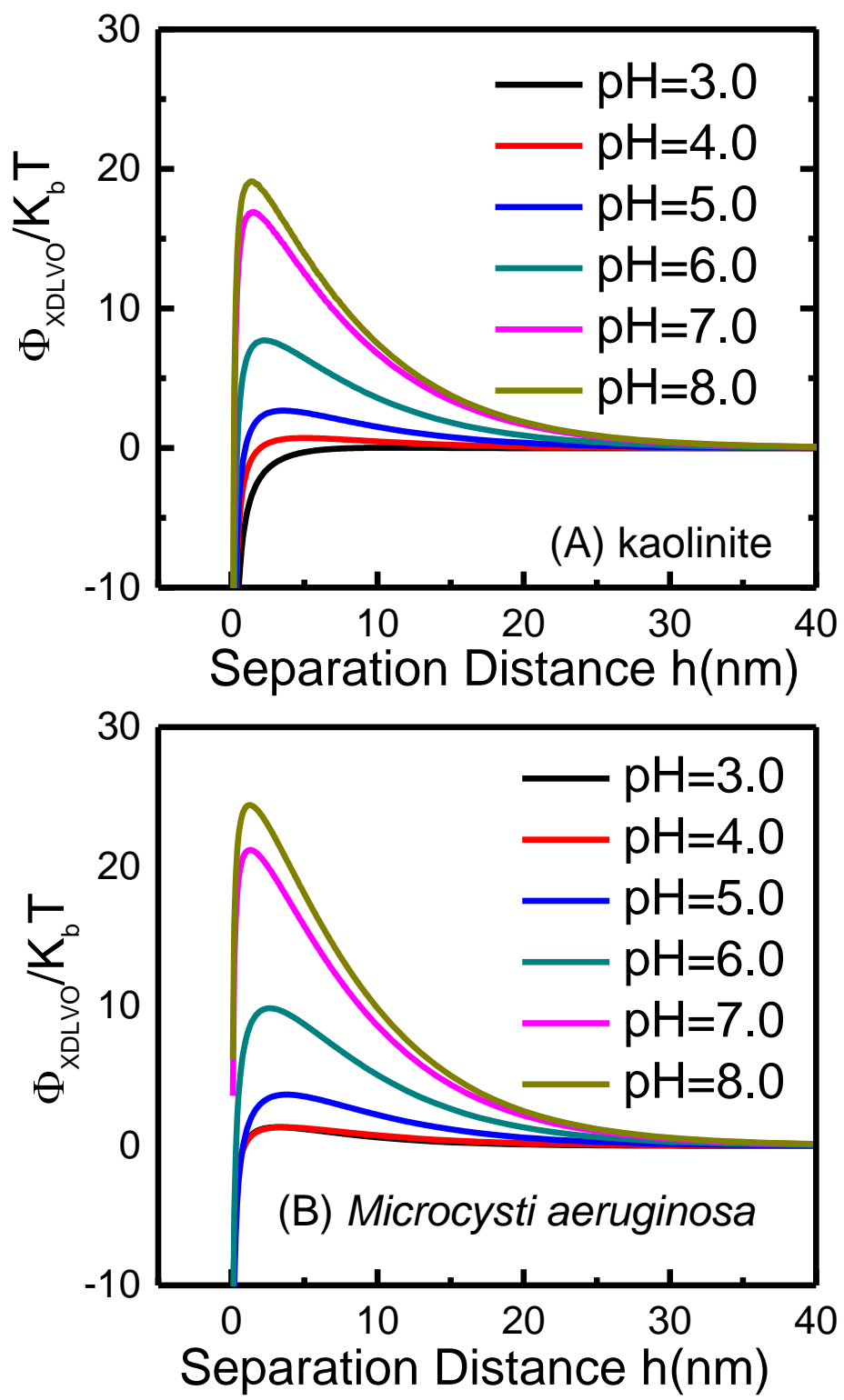

Fig. 4. Calculated XDLVO profiles at different pH values. (A) MS2-kaolinite. (B) MS2-Microcysti aeruginosa. The concentrations of kaolinite, Microcysti aeruginosa, and MS2 are $100 \mathrm{mg} / \mathrm{L}, 1.0 \times 10^{5}$ Cells $/ \mathrm{mL}$, and $1.0 \times 10^{8} \mathrm{pfu} / \mathrm{mL}$, respectively, $\mathrm{T}=25^{\circ} \mathrm{C}$. 

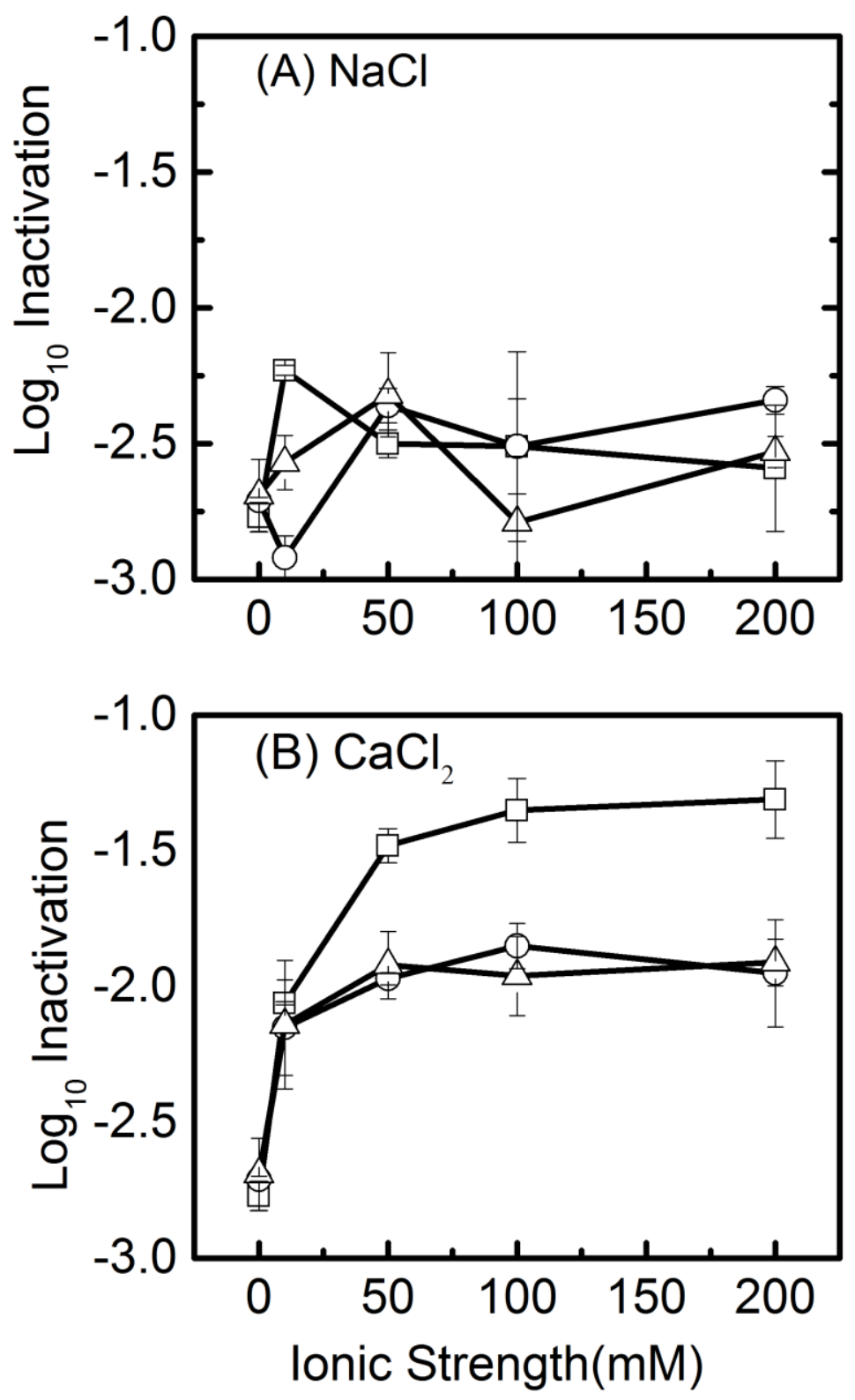

$\longrightarrow \square$ Particle-free Control $-\mathrm{O}-$ kaolinite $\rightarrow-$ Microcystis aeruginosa

Fig. 5. The log inactivation of MS2 by UV disinfection at different ionic strengths. (A) $\mathrm{NaCl}$. (B) $\mathrm{CaCl}_{2}$. The concentrations of kaolinite, Microcysti aeruginosa, and MS2 are $100 \mathrm{mg} / \mathrm{L}, 1.0 \times 10^{5} \mathrm{Cells} / \mathrm{mL}$, and $1.0 \times 10^{8} \mathrm{pfu} / \mathrm{mL}$, respectively, contact time is 1 minute, $\mathrm{pH}=7.0, \mathrm{~T}=25^{\circ} \mathrm{C}$. 

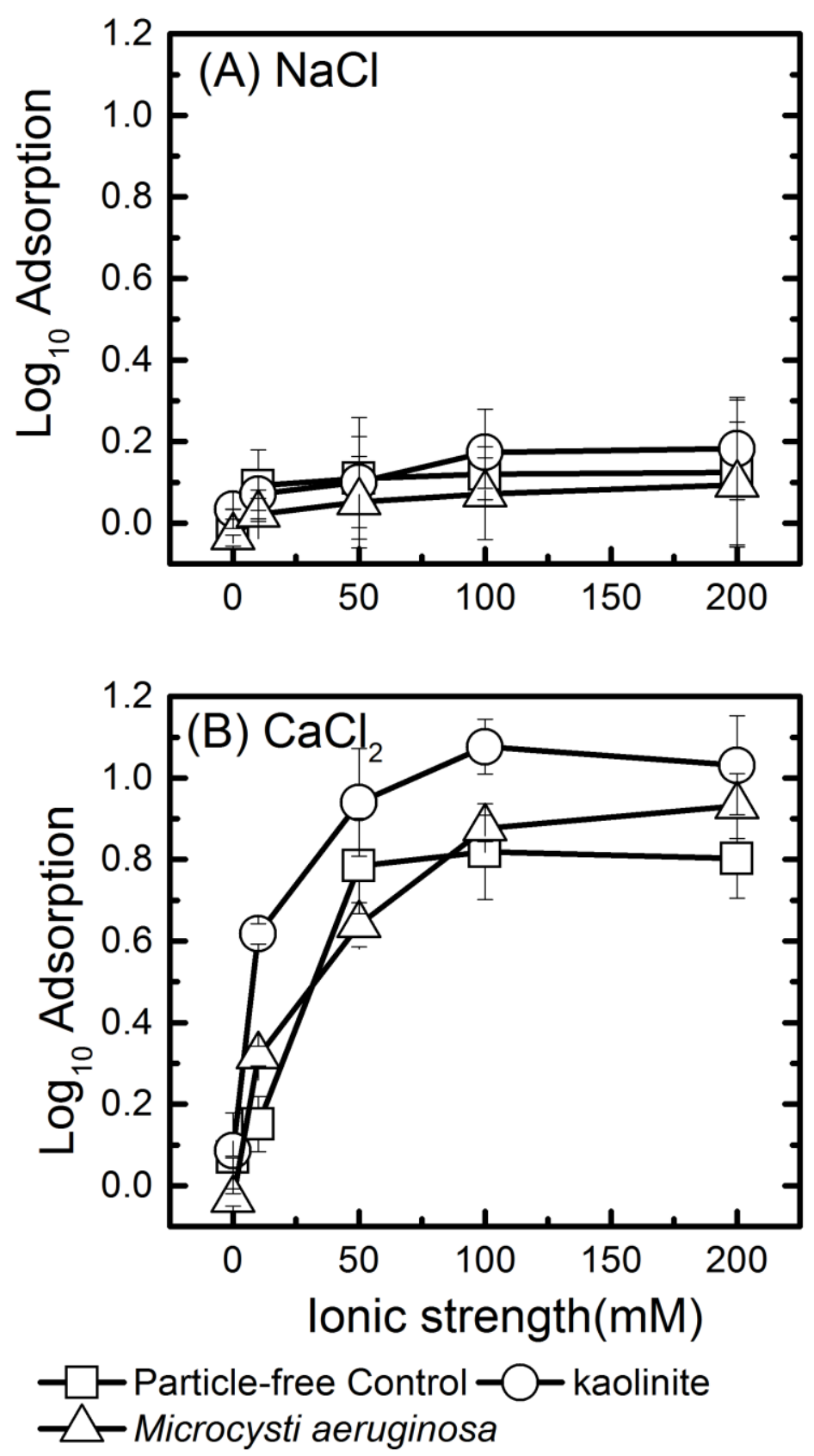

Fig. 6. The log adsorption of MS2 at different ionic strengths. (A) $\mathrm{NaCl}$. (B) $\mathrm{CaCl}_{2}$. The concentrations of kaolinite, Microcysti aeruginosa, and MS2 are $100 \mathrm{mg} / \mathrm{L}$, $1.0 \times 10^{5} \mathrm{Cell} / \mathrm{s} / \mathrm{mL}$, and $1.0 \times 10^{8} \mathrm{pfu} / \mathrm{mL}$, respectively, $\mathrm{pH}=7.0, \mathrm{~T}=25^{\circ} \mathrm{C}$. 


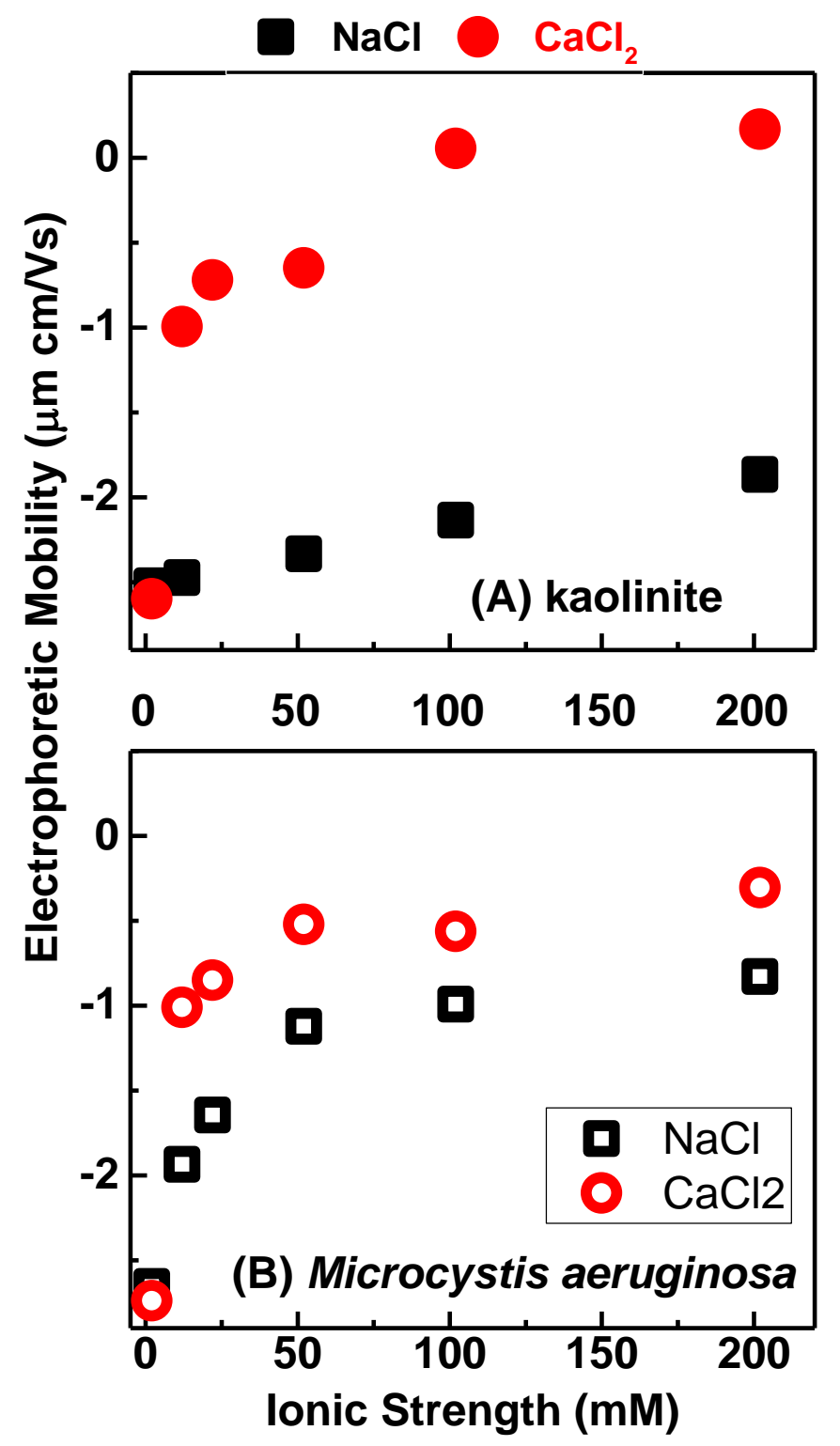

Fig. 7. The electrophoretic mobility of (A) kaolinite and (B) Microcystis aeruginosa at different ionic strengths of $\mathrm{NaCl}$ (black squares) and $\mathrm{CaCl}_{2}$ (red circles). The concentrations of kaolinite and Microcysti aeruginosa are $100 \mathrm{mg} / \mathrm{L}$ and $1.0 \times 10^{5}$ Cells $/ \mathrm{mL}$, respectively, $\mathrm{pH}=7.0, \mathrm{~T}=25^{\circ} \mathrm{C}$. 


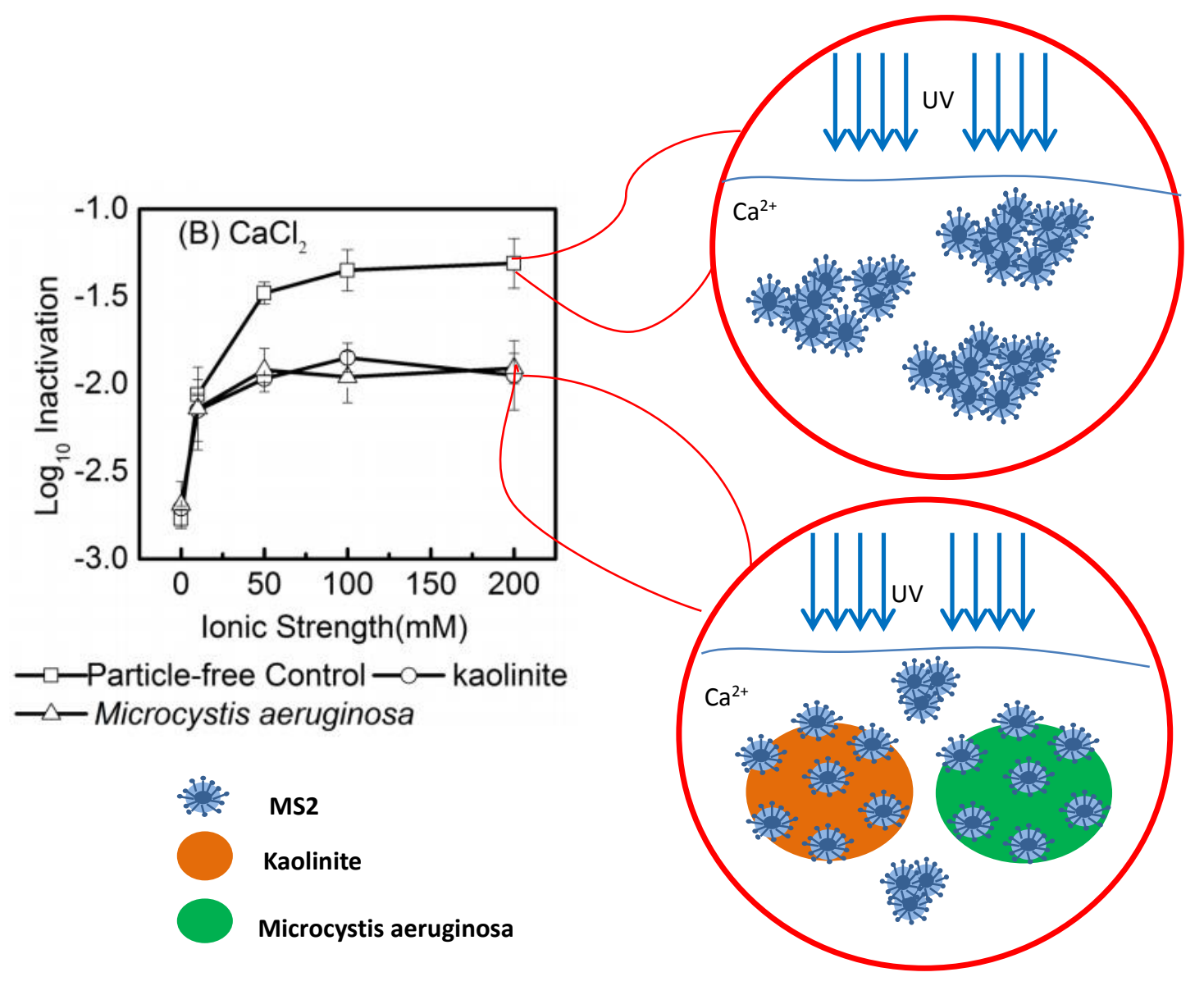

